\title{
Rapid and extensive lethal action of clofibrate on hepatoma cells in vitro
}

\author{
Rosa A. Canuto ${ }^{1,4}$, Giuliana Muzio², Marina Maggiora', \\ Riccardo Autelli ${ }^{2}$, Giuseppe Barbiero ${ }^{2}$, Paola Costelli ${ }^{2}$, \\ Gabriella Bonelli $^{2}$ and Francesco M. Baccino ${ }^{2,3}$ \\ Dipartimento di Scienze Cliniche e Biologiche, Università di Torino, Ospedale \\ San Luigi Gonzaga, 10043 Orbassano (Torino) \\ 2 Dipartimento di Medicina ed Oncologia Sperimentale, Università di Torino, \\ Corso Raffaello 30, 10125 Torino \\ ${ }^{3}$ Centro CNR di Immunogenetica ed Oncologia Sperimentale, Torino, Italy \\ ${ }^{4}$ Corresponding author: Dipartimento di Scienze Cliniche e Biologiche, \\ Università di Torino, Ospedale San Luigi Gonzaga, Regione Gonzole 10, 10043 \\ Orbassano (Torino) - Italy. tel: 0039-11-9038615; fax: 0039-11-9038639; \\ e-mail: baccino@polito.it
}

Received 22.8.96; revised 11.10.96; accepted 29.10.96 Edited by R.A. Knight

\begin{abstract}
Clofibrate, for a long time in use as a hypolipidemic drug, is a well known peroxisomal proliferator (PP) and hepatocarcinogen in rodents. We show here that in vitro $1 \mathrm{mM}$ clofibrate induces a rapid and massive death of rat AH-130 hepatoma cells. Cell death was prominent already after $4 \mathrm{~h}$ of treatment, with a characteristic 'apoptotic' pattern by conventional microscopy. This was further supported by the pronounced chromatin condensation detectable on 4',6-diamine-2'-phenylindole dihydrochloride (DAPI) staining, the clearcut internucleosomal DNA fragmentation on agarose-gel electrophoresis (ladder patten), and the accumulation of markedly hypochromic cells observed in flow cytometric DNA histograms. Consistently with the apoptotic features of the process, some parameters commonly used to detect cell death, such as plasma membrane permeabilization to trypan blue or propidium iodide, lack of mitochondrial retention of rhodamine 123 , or extracellular release of lactate dehydrogenase, were all virtually negative. However, these same parameters became markedly positive after $24 \mathrm{~h}$ of treatment, which was suggestive for the occurrence of 'secondary' necrosis among $\mathrm{AH}-130$ cells. By a combination of flow cytometric parameters, after $4 \mathrm{~h}$ on $1 \mathrm{mM}$ clofibrate only $41 \%$ of the $\mathrm{AH}-130$ cells could still be categorized as viable (i.e., non-apoptotic and non-necrotic), while $46 \%$ of cells appeared apoptotic and $13 \%$ necrotic. At $24 \mathrm{~h}, 67 \%$ of cells were necrotic, $20 \%$ apoptotic and only $13 \%$ non-apoptotic and nonnecrotic. Apoptosis was also extensive in $\mathrm{AH}-130$ cells treated with another PP such as nafenopin at $1 \mathrm{mM}$ concentration and in human hepatoma HepG2 cells treated with clofibrate. By contrast, clofibrate did not cause apoptosis on primary rat hepatocyte cultures. These observations indicate that: (i)
\end{abstract}

apart from their well-known cell growth-promoting action, PPs such as clofibrate or nafenopin may exert a substantial cytotoxic action on targets such as the AH-130 or HepG2 hepatoma cells; (ii) this cell death evolves from an initial 'apoptotic' to an eventual 'necrotic' pattern; (iii) detection of cell death requires the adoption of a full panel of tests, adequate to cover the whole evolving death pattern, while such tests may even be substantially misleading whenever applied individually; (iv) the cytotoxicity of clofibrate and similar agents on normal and, particularly, tumoural cells may deserve careful reevaluation.

Keywords: cell death, apoptosis, necrosis, hepatoma cells, peroxisome proliferators, clofibrate, nafenopin

Abbreviations: AGE, agarose-gel electrophoresis; DAPI, 4',6diamine-2'-phenylindole dihydrochloride; $F L$, fluorescence channel; FSC, forward light scatter; HMGCoA, 3-hydroxy-3methylglutaryl-coenzyme A; LDH, lactate dehydrogenase; PBS, phosphate-buffered saline; $\mathrm{PI}$, propidium iodide; $\mathrm{PP}$, peroxisome proliferator; PPAR, PP-activated receptor; R123, rhodamine 123; SSC, side light scatter; TB, trypan blue

\section{Introduction}

The carcinogenic action of PPs is widely documented. Since PPs do not damage DNA directly, these agents are usually categorized as nongenotoxic carcinogens (e.g. Reddie and Lalwai, 1983; Bursch et al, 1992; Chen et al, 1994). Yet genotoxicity may arise indirectly, due to excess reactive oxygen species and lipid peroxidation products generated in consequence of the PP-induced elevation of peroxisomal $\beta$ oxidation enzymes; of special importance, in this connection, is fatty acyl-CoA oxidase, which has hydrogen peroxide as a byproduct (Reddie and Lalwai, 1983; Hwang et al, 1993). The induction of these enzymes, as well as of the microsomal cytochrome P450 IVA or of the mitochondrial HMGCoA synthase (Rodriguez et al, 1994), is specifically mediated by the PPAR. This is a member of the steroid hormone receptor superfamily that recognizes PP-response elements in the upstream promoter region of the responsive genes and thereby activates their transcription (reviewed in Green and Wahli, 1994). The action as tumour promoters is most often ascribed to enhanced liver cell proliferation (Reddie and Lalwai, 1983; Chen et al, 1994, and references therein). PPs may indeed stimulate cell growth in vivo (Ohmura et al, 1996). In cells of the hepatocytic lineage mitogenesis by amphipathic carboxylates, the main PP class that includes clofibrate, specifically involves their interaction with the liver fatty acidbinding protein (Khan and Sorof, 1994, and references therein). An additional mechanism, not necessarily alternative, stems from the observation that cell death by apoptosis in 
preneoplastic or early neoplastic liver lesions is suppressed by a variety of tumour promoters, including PPs (SchulteHermann et al, 1987; Bursch et al, 1992; Columbano et al, 1996). Consistently, a PP such as nafenopin $(50 \mu \mathrm{M})$ has recently been reported to promote the survival of cells of the hepatocytic lineage in vitro (Bayly et al, 1994; Gill et al, 1995).

In the course of experiments aimed at altering the lipid composition of tumour cells, we found, unexpectedly, that $1 \mathrm{mM}$ clofibrate induced rapid and massive death of Yoshida $\mathrm{AH}-130$ ascites hepatoma cells in vitro. The same result was obtained on human hepatoma HepG2 cells, while only $\mathrm{AH}-130$ cells were killed by another PP, nafenopin, at $1 \mathrm{mM}$ concentration. Clofibrate, discovered some 30 years ago (Thorp and Waring, 1962), has long been in use as a hypolipidemic drug (briefly reviewed in Hahn and Goldberg, 1992). The mechanism of the hypolipidemic action of clofibrate or other fibric acid derivatives, some still of clinical relevance, is not yet clear (Hahn and Goldberg, 1992; Green and Wahli, 1994). In the liver of rodents, clofibrate and other PPs cause conspicuous increases in size and number of peroxisomes, hyperplasia and hepatocellular carcinomas (Reddie and Lalwai, 1983).

In the present paper, we report on the death of rodent and human hepatoma cells by clofibrate and nafenopin, show that it occurs by the apoptotic mode, and briefly discuss the possible relevance of this finding to the action of clofibrate and related agents as tumour promoters. In addition, the present data, further expanding previous observations and concepts (Darzynkiewicz et al, 1992; Dive et al, 1992), suggest that this clofibrate-induced cell death can be proposed as a useful model to illustrate the relative merit and reliability of a panel of procedures commonly employed in cytotoxicity testing.

\section{Results}

Microscopy

The basic morphological changes occurring in $\mathrm{AH}-130$ cells exposed to $1 \mathrm{mM}$ clofibrate are illustrated in Figure $1 \mathrm{~B}$ and $\mathrm{C}$. Cell shrinkage due to nuclear and cytoplasmic condensation was clearly detectable at $4 \mathrm{~h}$ and involved a substantial fraction of the population by $24 \mathrm{~h}$. As observed after DAPIstaining, a striking pattern of chromatin condensation associated with polylobation or fragmentation of nuclei was already prominent by $4 \mathrm{~h}$. A similar pattern was observed when $\mathrm{AH}-130$ cells were incubated in the presence of $1 \mathrm{mM}$ nafenopin (Figure 1D).

After 4 and $24 \mathrm{~h}$ incubation, the percentage of apoptotic cells (apoptotic index, data not shown) amounted to 48 and $95 \%$, respectively, for cells treated with $1 \mathrm{mM}$ clofibrate and to 37 and $94 \%$, respectively, for those on $1 \mathrm{mM}$ nafenopin. Lower concentrations of either drug $(0.05 \mathrm{mM})$ did not cause any appreciable increase of the apoptotic index over the values recorded for controls, incubated with the solvents alone ( 2 and $8 \%$ at 4 and $24 \mathrm{~h}$, respectively).

Moreover, at variance with its previously reported action on rat hepatocytes or $\mathrm{FaO}$ hepatoma cells (Bayly et al, 1994; Gill et al, 1995), 0.05 mM nafenopin did not display any protective effect on $\mathrm{AH}-130$ cells against apoptosis either spontaneous or induced by $1 \mathrm{mM}$ clofibrate.
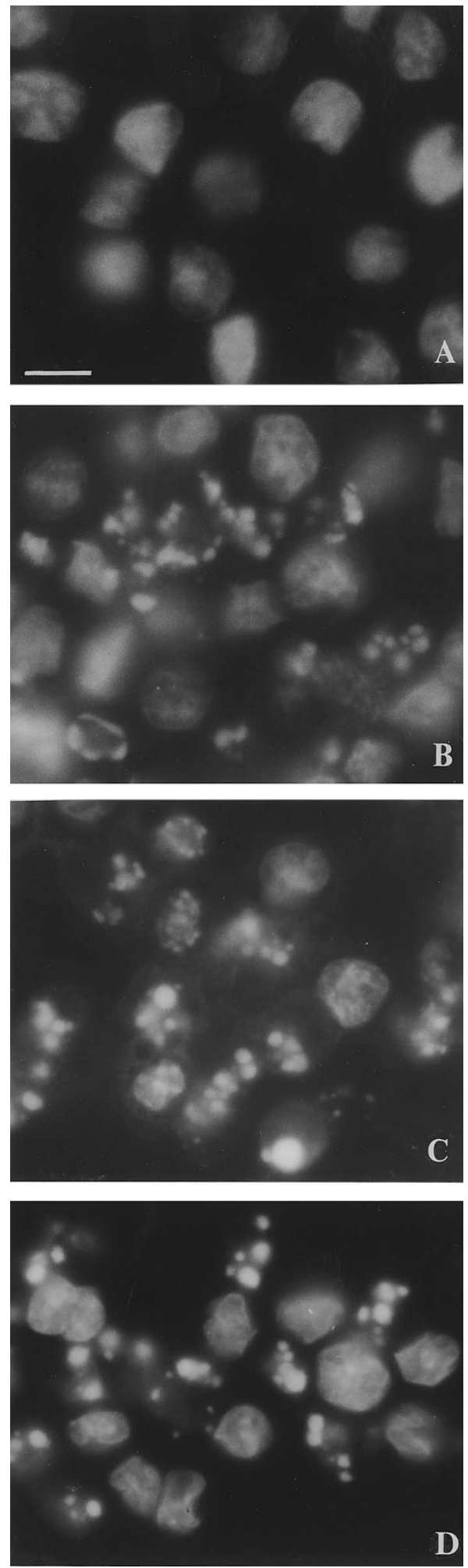

Figure 1 Light microscopic appearance of PP-induced apoptosis in $\mathrm{AH}-130$ cells. Control cells $(A)$ and cells after $4 \mathrm{~h}(B)$ and $24 \mathrm{~h}(\mathrm{C})$ on $1 \mathrm{mM}$ clofibrate or after $4 \mathrm{~h}$ on $1 \mathrm{mM}$ nafenopin (D), stained with DAPI. Bar (A-D): $10 \mu \mathrm{m}$. 

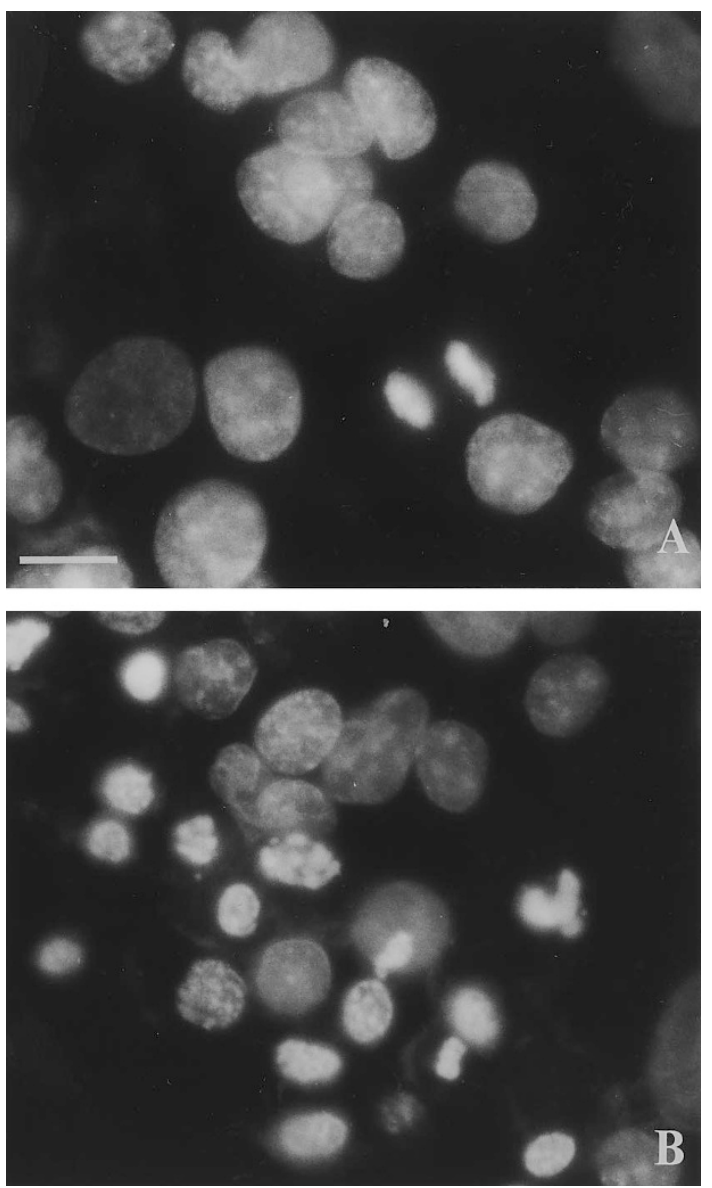

Figure 2 Light microscopic appearance of clofibrate-induced apoptosis in HepG2 cells. Control cells (A) and cells after $4 \mathrm{~h}$ on $1 \mathrm{mM}$ clofibrate $(B)$, stained with DAPI. Bar $(\mathrm{A}-\mathrm{B}): 10 \mu \mathrm{M}$.
The cytotoxicity of clofibrate was also assessed on other cell types. No apoptosis was caused by this drug, at concentrations up to $1 \mathrm{mM}$, in primary cultures of rat hepatocytes (data not shown). By contrast, $1 \mathrm{mM}$ clofibrate was clearly apoptogenic for human hepatoma HepG2 cells (Figure 2B; the percentage of cells with a $<2 n$ DNA fluorescence, by flow cytometry, was $1 \%$ at time $0,5 \%$ at $2 \mathrm{~h}, 19 \%$ at $4 \mathrm{~h}, 26 \%$ at $8 \mathrm{~h}$ ). The HepG2 cells, however, were not affected by treatment with $1 \mathrm{mM}$ nafenopin.

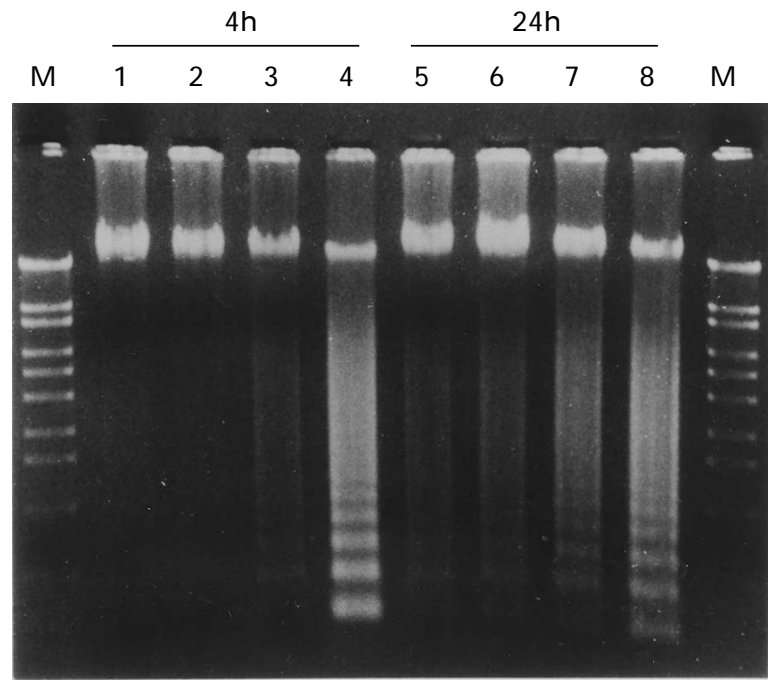

Figure 3 Agarose gel electrophoresis of DNA. DNA from $\mathrm{AH}-130$ cells incubated for $4 \mathrm{~h}$ or $24 \mathrm{~h}$, as indicated, with no clofibrate (controls: lanes 1 and 5) or with $0.25 \mathrm{mM}$ (lanes 2 and 6 ), $1.0 \mathrm{mM}$ (lanes 3 and 7), and $2 \mathrm{mM}$ (lanes 4 and 8) clofibrate. Molecular weight markers (M): Styl digest of $\phi$.

\section{$\mathrm{C} 24 \mathrm{~h}$}

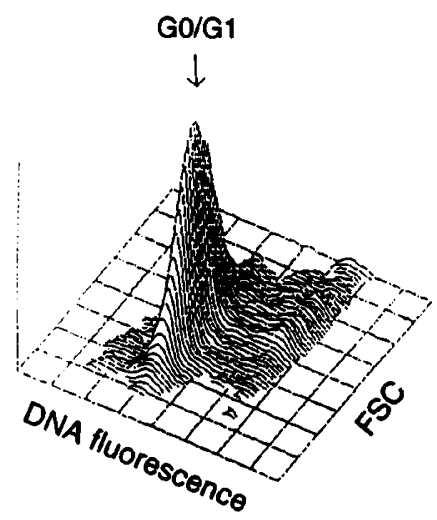

$\mathrm{CL} 4 \mathrm{~h}$

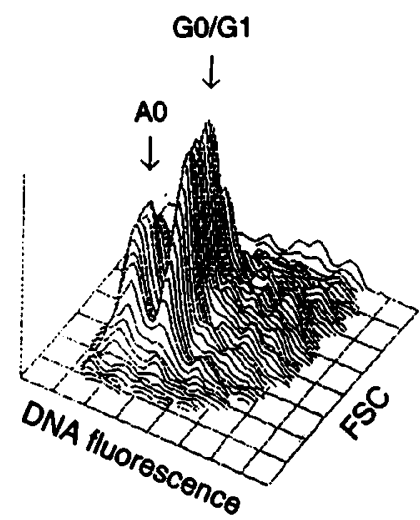

$\mathrm{CL} 24 \mathrm{~h}$

AO

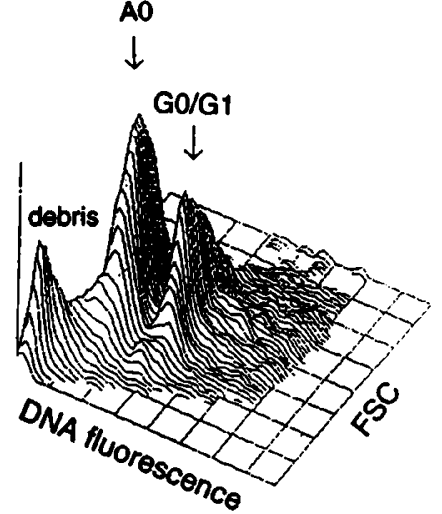

Figure 4 Forward light scatter (FSC) vs DNA fluorescence. Representative contour plots of ethanol-fixed AH-130 cells: control cells at $24 \mathrm{~h}$ (left panel) and cells exposed to $1 \mathrm{mM}$ clofibrate for $4 \mathrm{~h}$ (center) and $24 \mathrm{~h}$ (right). A0 region denotes cells with a normal size (FSC) and a subdiploid DNA fluorescence, well distinct from debris. 


\section{DNA electrophoresis}

Cleavage of nuclear DNA into multiples of $180-200 \mathrm{bp}$, detectable as 'DNA laddering' by AGE, is usually considered a hallmark of apoptosis (reviewed in Peitsch et al, 1994). Analysis of the DNA extracted from clofibrate-treated $\mathrm{AH}-130$ cells showed (Figure 3 ) a clearcut ladder pattern at both 4 and $24 \mathrm{~h}$, the extent of DNA fragmentation increasing with exposure time and clofibrate concentration. Although in some systems such internucleosomal chromatin cleavage is not detectable, its occurrence confirms the apoptotic nature of the process.

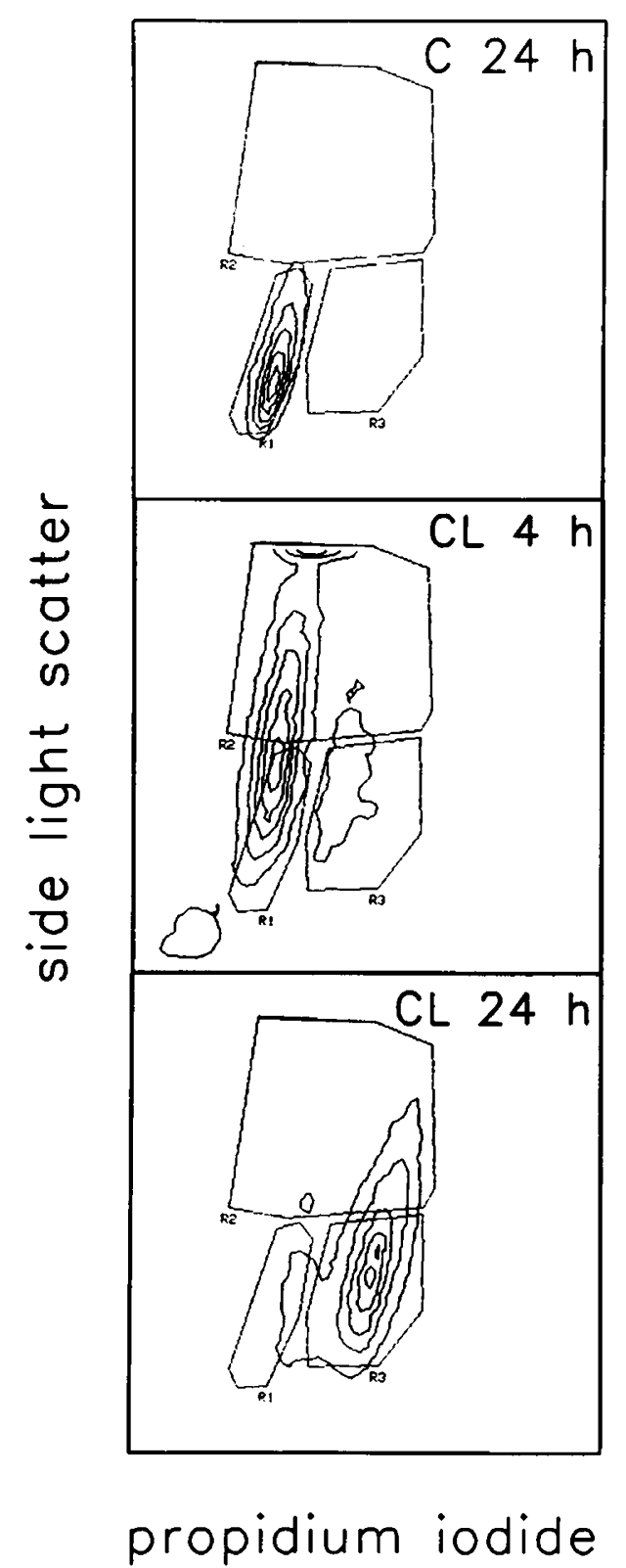

Figure 5 Side light scatter (SSC) vs PI exclusion. Representative contour plots of unfixed $\mathrm{AH}-130$ cells: control cells at $24 \mathrm{~h}$ (top panel) and cells exposed to $1 \mathrm{mM}$ clofibrate for $4 \mathrm{~h}$ (center panel) and $24 \mathrm{~h}$ (bottom panel), as indicated. Areas indicated as R1, R2, R3 correspond to viable, early and late apoptotic cells, respectively, as defined in the legend to Figure 6.

\section{Flow cytometry}

The death process elicited by clofibrate in $\mathrm{AH}-130$ cells was analyzed in detail flow cytometrically (cf. Darzynkiewicz et al, 1992; Dive et al, 1992). At $4 \mathrm{~h}$, the onset of apoptosis was associated with an increased SSC of cells, in agreement with previous observations (Swat et al, 1991; Barbiero et al, 1995), though basal SSC levels had recovered by $24 \mathrm{~h}$ (not shown). Figure 4 illustrates the distribution of DNA fluorescence vs FSC, a parameter for cell size. In control cells, the pattern after $24 \mathrm{~h}$ in vitro was similar to that observed at time 0 or after a $4 \mathrm{~h}$ incubation (not shown). In cells exposed to $1 \mathrm{mM}$ clofibrate, flow cytometry detected a substantial accumulation of cells characterized by a $<2 n$ DNA fluorescence (in the A0 region, according to Telford et al, 1991). Already prominent after a $4 \mathrm{~h}$ treatment, when it accounted for $41 \pm 7 \%$ of cells, this subpopulation became even more conspicuous by $24 \mathrm{~h}$ $(63 \pm 8 \%)$, when also the FSC was decreased. A further peak, well distinct from the A0 region, was evident at $24 \mathrm{~h}$ (Figure 4, right): characterized by very low FSC and faint $\mathrm{PI}$ staining, it represented debris from necrotic cells (cf. Darzynkiewicz et al, 1992; Dive et al, 1992).

Figure 5 illustrates how the distribution of $\mathrm{AH}-130$ cells treated with $1 \mathrm{mM}$ clofibrate evolved with respect to two other parameters evaluated on non-fixed cells, namely, SSC, which reflects 'cell density', and PI exclusion, as a measure of plasma membrane integrity. SSC was substantially increased at $4 \mathrm{~h}$, as often observed in apoptosing cells (Swat et al, 1991; Barbiero et al, 1995), though by $24 \mathrm{~h}$ it had largely receded to control levels. Figure 5 further shows that PI, while excluded by virtually all of the control cells and by most of those treated with $1 \mathrm{mM}$ clofibrate for $4 \mathrm{~h}$, was taken up by the vast majority of cells after $24 \mathrm{~h}$ on clofibrate; this finding argues for the occurrence of 'secondary necrosis' among $\mathrm{AH}-130$ cells (Wyllie et al, 1980; Desjardins and MacManus, 1995).

As a further viability test, $\mathrm{R} 123$ mitochondrial retention in $\mathrm{AH}-130$ cells was evaluated by flow cytometry (not shown). This parameter closely correlated with $\mathrm{PI}$-exclusion in both control and experimental cells. On $1 \mathrm{mM}$ clofibrate, cells that did not retain $\mathrm{R} 123$ were $>14 \%$ at $4 \mathrm{~h}$, but amounted to $>65 \%$ by $24 \mathrm{~h}$. In other models of apoptosis (Barbiero et al, 1995, and reviewed in Kroemer et al, 1995) the integrity of mitochondria is compromised earlier than that of the plasma membrane or of lysosomes (by acridine orange retention).

The overall information obtained by flow cytometry is summarized in Figure 6. As detailed in the legend, combining different flow cytometric parameters (DNA fluorescence, FSC, SSC, PI exclusion, R123 retention) permitted to discriminate among viable (neither necrotic nor apoptotic), early apoptotic, and late apoptotic $\mathrm{AH}-130$ cell subpopulations. Control cells were virtually all viable at $4 \mathrm{~h}$, and still $>90 \%$ viable by $24 \mathrm{~h}$. On $1 \mathrm{mM}$ clofibrate, not more than $41 \%$ of the population could be considered viable by $4 \mathrm{~h}$, and only $13 \%$ by $24 \mathrm{~h}$, which figures are pretty close to those obtained microscopically by counting the proportion of apoptotic cells (see above). It is clear, though, that at $4 \mathrm{~h}$ most dying cells were still at an early 


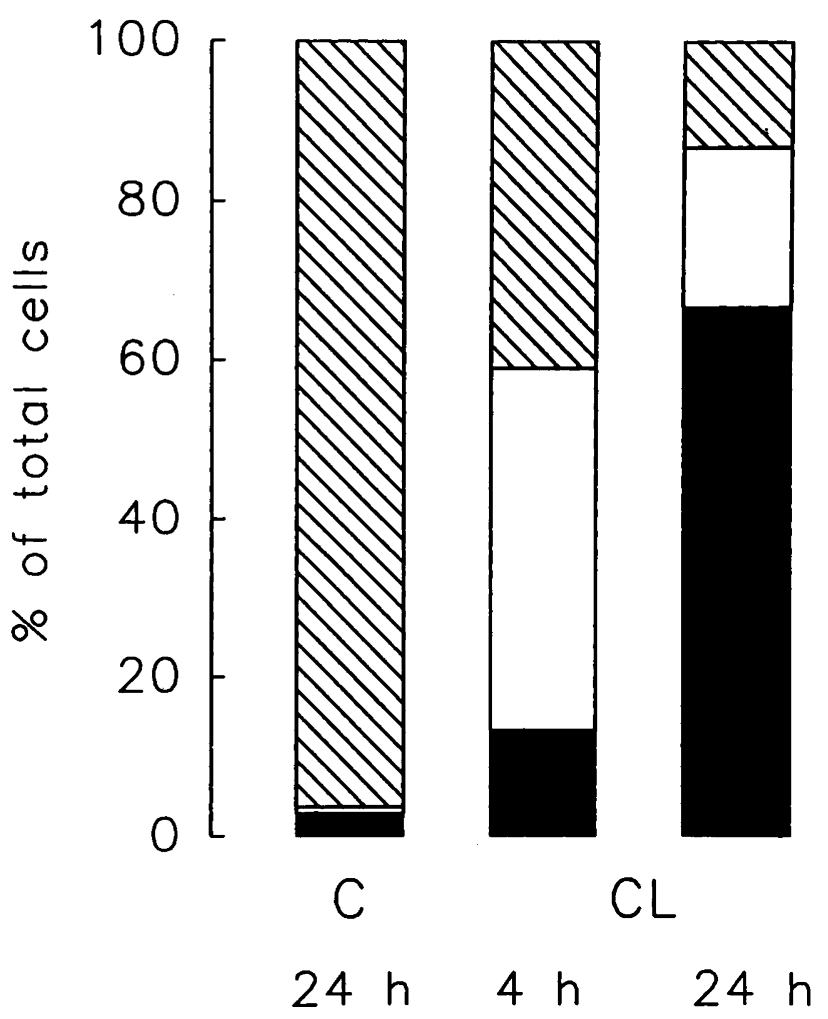

Figure 6 Frequency of apoptotic cells by flow cytometry. AH-130 cells incubated with no clofibrate $(C)$ or with $1 \mathrm{mM}$ clofibrate $(C L)$ for $4 \mathrm{~h}$ and $24 \mathrm{~h}$. Based on combined flow-cytometric parameters, as evaluated on fixed or unfixed cells, cells were attributed to three classes: (1) viable (dashed bars): that is non-apoptotic and non-necrotic: with normal SSC, excluding PI, retaining R123, and outside the A0 region; (2) early apoptotic (open bars): with increased SSC, excluding $\mathrm{PI}$, retaining $\mathrm{R} 123$, and included in the $\mathrm{A} 0$ region; (3) late apoptotic (full bars): with normal SSC, not excluding $\mathrm{PI}$, not retaining R123, and included in the A0 region ('secondary necrosis', Wyllie et al, 1980). Data expressed as percentages of total cells (means of three experiments). Differences between means were statistically significant $(p<0.05)$ on ANOVA followed by Newman-Keuls test.

stage of the apoptotic process, and only a few (13\%) at a late stage, whereas by $24 \mathrm{~h}$ two-thirds of the cells were at a late apoptotic stage.

\section{Conventional cell integrity parameters}

The effect of clofibrate on $\mathrm{AH}-130$ cell integrity was further evaluated by two routine procedures, namely TB exclusion and $\mathrm{LDH}$ release (Tables 1 and 2). In controls or in cells incubated with 0.05 or $0.25 \mathrm{mM}$ clofibrate at both 4 and $24 \mathrm{~h}$, only a negligible fraction of cells failed to exclude the dye. By contrast, on $1 \mathrm{mM}$ clofibrate the proportion of cells stained by TB at $4 \mathrm{~h}$ increased moderately, while about $70 \%$ of the cells became permeable to TB by $24 \mathrm{~h}$. Moreover, a significant decrease of cell number was observed only after $24 \mathrm{~h}$ treatment with $1 \mathrm{mM}$ clofibrate (Table 3 ). These figures are consistent with those obtained flow-cytometrically with the PIexclusion test (see Figures 4 and 5).

Although basically similar, the LDH release data (Table 2) indicate a degree of damage slightly higher than that measured by TB-exclusion testing. At first sight, this may appear surprising for a small molecule such as TB (or PI) should cross a 'leaky' plasma membrane much more easily than LDH. However, the results of simple counts showed that in $24 \mathrm{~h} 1 \mathrm{mM}$ clofibrate caused a 14\% decrease in the total number of cells. Since this change presumably reflected, in part at least, complete disintegration of a significant proportion of cells, the corresponding contribution of LDH to the medium probably accounted for the excess cell death measured by LDH release vs the values detected by TB-exclusion testing.

TB exclusion and LDH release were also evaluated on cells exposed to nafenopin (Tables 1 and 2). The results with $0.05 \mathrm{mM}$ nafenopin at 4 and $24 \mathrm{~h}$ (data not shown) and with $1 \mathrm{mM}$ nafenopin at $4 \mathrm{~h}$ closely reproduced those obtained with clofibrate at corresponding concentrations and times. By contrast, leakiness to TB and $\mathrm{LDH}$ release were both markedly lower after $24 \mathrm{~h}$ on $1 \mathrm{mM}$ nafenopin than on clofibrate and, consistently, the number of nafenopin-treated cells did not decrease significantly (data not shown).

\section{Discussion}

The present observations show that clofibrate and nafenopin were rapidly and extensively lethal for rat ascites hepatoma $\mathrm{AH}-130$ cells in vitro. Also the HepG2 cells, a human hepatoma line, were rapidly killed by clofibrate, though less extensively than the $\mathrm{AH}-130$ cells, but nafenopin had no lethal action on them. Other rat hepatoma cells (JM2 and Morris 7777, unpublished observations) or rat hepatocytes in primary culture were not affected by clofibrate. This induced cell death, which occurred by apoptosis, was particularly investigated on clofibrate-treated $\mathrm{AH}-130$ cells.

Clofibrate was apoptogenic at $1 \mathrm{mM}$, which apparently is a quite high concentration; however, similar or even higher concentrations have been used in biochemical studies on tissue cultures (Chawla and Lazar, 1994; Perrot et al, 1991), and $250 \mathrm{mg} / \mathrm{kg} \mathrm{b.w.} \mathrm{is} \mathrm{a} \mathrm{usual} \mathrm{dosage} \mathrm{for} \mathrm{clofibrate}$ in rat chemical hepatocarcinogenesis protocols (cf. Reddy and Lalwai, 1983).

\section{The death process in $\mathrm{AH}-130$ cells}

Apoptosis is the mode by which the $\mathrm{AH}-130$ cells spontaneously die in the animal at rates that increase as the tumour shifts from the exponential to the plateau growth phase (Tessitore et al, 1993). In AH-130 cells treated with $1 \mathrm{mM}$ clofibrate, apoptosis was already prominent after $4 \mathrm{~h}$ and became massive by $24 \mathrm{~h}$. Cell death was easily detected by light microscopy, on smears stained with haematoxylin and eosin or DAPI, as well as by flow cytometry, from the appearance of a subpopulation of cells with a $<2$ n DNA fluorescence. Such hypodiploid peak or A0 region in the cytogram correlated with the occurrence of a clearcut internucleosomal DNA fragmentation, as detected by AGE (see Nicoletti et al, 1991; Telford et al, 1991). At $4 \mathrm{~h}$, the onset of apoptosis was associated with an increased SSC of cells, in agreement with previous observations (Swat et al, 1991; Barbiero et al, 1995), though basal SSC levels had recovered by $24 \mathrm{~h}$, most cells had shrunk to a smaller size, as 
Table 1 Effect of clofibrate and nafenopin on trypan blue exclusion in $\mathrm{AH}-130$ cells.

\begin{tabular}{|c|c|c|}
\hline & \multicolumn{2}{|c|}{ Incubation time } \\
\hline & $4 h$ & $24 \mathrm{~h}$ \\
\hline Controls & $0.4 \pm 0.1^{a}$ & $2.1 \pm 0.1^{a}$ \\
\hline Clofibrate & & $51+0$ \\
\hline $0.25 \mathrm{mM}$ & $2.0 \pm 0.1^{a}$ & $2.4 \pm 0.2^{\mathrm{a}}$ \\
\hline $1.00 \mathrm{mM}$ & $9.4 \pm 0.6^{b}$ & $68.1 \pm 9.5^{\circ}$ \\
\hline Nafenopin & & \\
\hline $1.00 \mathrm{mM}$ & $3.0^{*}$ & $16.4^{*}$ \\
\hline
\end{tabular}

Data expressed as percentages of cells not excluding trypan blue (means \pm SD, $n=6)$. Differences between groups labelled with different letters are statistically significant $(p<0.05)$ on ANOVA followed by Newman-Keuls test. *Data refer to two experiments.

Table 2 Effect of clofibrate and nafenopin on lactate dehydrogenase release from $\mathrm{AH}-130$ cells

\begin{tabular}{lcc}
\hline & \multicolumn{2}{c}{ Incubation time } \\
& $\mathbf{4} \mathbf{~ h}$ & $\mathbf{2 4} \mathbf{~ h}$ \\
\hline Controls & $3.0 \pm 0.2^{\mathrm{a}}$ & $10.3 \pm 0.9^{\mathrm{b}}$ \\
Clofibrate & $7.4 \pm 0.3^{\mathrm{ab}}$ & $9.8 \pm 1.0^{\mathrm{b}}$ \\
$0.25 \mathrm{mM}$ & $9.7 \pm 0.5^{\mathrm{b}}$ & $77.8 \pm 9.4^{\mathrm{c}}$ \\
$1.00 \mathrm{mM}$ & $5.3^{\star}$ & $28.9^{\star}$ \\
Nafenopin & & \multicolumn{1}{c}{} \\
$1.00 \mathrm{mM}$ & &
\end{tabular}

Lactate dehydrogenase (LDH) activity released to the medium expressed as percentage of the total activity in cell suspensions. Total LDH activity at time 0 corresponded to $783 \pm 108$ nmoles of $\mathrm{NADH}$ consumed/min per $10^{6}$ cells. Presentation and statistical analysis of data as in Table 1.

Table 3 Effect of clofibrate on $\mathrm{AH}-130$ cell number

\begin{tabular}{lcc}
\hline Clofibrate $(\mathbf{m M})$ & \multicolumn{2}{c}{ Incubation time } \\
\hline 0 & $\mathbf{4} \mathbf{h}^{\text {In }}$ \\
0.25 & $470 \pm 73^{\mathrm{ab}}$ & $525 \pm 78^{\mathrm{b}}$ \\
1.00 & $469 \pm 69^{\mathrm{ab}}$ & $544 \pm 62^{\mathrm{b}}$ \\
\hline
\end{tabular}

Values expressed as $10^{4}$ cells/ml suspension; ${ }^{a} 400$ was the seeding density and thus is the time 0 figure for all groups. Presentation and statistical analysis of data as in Table 1.

also denoted by the decreased FSC, and had generally progressed to more advanced stages of the apoptotic process. Notably, after $4 \mathrm{~h}$ on $1 \mathrm{mM}$ clofibrate virtually all cells appeared 'viable' by conventional tests for cell necrosis that measure either the leakiness of plasma membranes to dyes such as trypan blue (by light microscopy) and propidium iodide (by flow-cytometry) or the extracellular release of cytoplasmic constituents such as LDH. Therefore, these tests almost totally failed to diagnose an already conspicuous cell death process, which, by contrast, was clearly detected using appropriate procedures that have been recently developed to monitor and quantify apoptosis. By $24 \mathrm{~h}$, cell death was also demonstrated with conventional tests for cell necrosis. Flow cytometric techniques were particularly apt to monitor the death process, for they rapidly discriminated between apoptotis and necrosis or between early and late stages of apoptosis in the whole cell population (Darzynkiewicz et al, 1992; Dive et al, 1992). However, once dead cells had fully disintegrated, death could only be measured by a test such as the $\mathrm{LDH}$ release assay. Of interest, the development of such secondary changes was far less pronounced when apoptosis was elicited by $1 \mathrm{mM}$ nafenopin, as consistently shown by all the parameters measured (apoptotic index, TB exclusion, $\mathrm{LDH}$ release). The reason for such a difference remains obscure, however. By all evidence, clofibrate or nafenopin caused death in $\mathrm{AH}-130$ cells mainly by the apoptotic mode, while only subsequently the apoptosed cells, particularly those exposed to clofibrate, underwent changes that can be conventionally categorized as 'secondary necrosis' (Wyllie et al, 1980; Desjardins and MacManus, 1995).

\section{Mechanisms of the lethal action of clofibrate and nafenopin}

An analysis of the mechanism(s) underlying the apoptogenic action of clofibrate and nafenopin on the rat $\mathrm{AH}-130$ cells and the reason why the human HepG2 cells were only susceptible to clofibrate is beyond the scope of the present report, and can only be conjectural thus far.

Among the pleiotropic effects of clofibrate, shared with nafenopin only in part, many are potentially relevant to induction of apoptosis. Suppression of DNA and RNA synthesis (Parekh and Chitins, 1991) or inhibition of HMGCoA reductase (Castillo et al, 1990; Haughom and Spydevold, 1992) might well play a role, since apoptosis may be caused by inhibitors of macromolecular syntheses (e.g. Hickman, 1992; Amenta et al, 1993; Sherwood and Schimke, 1994; Barbiero et al, 1995) or by the HMGCoA reductase inhibitor lovastatin (e.g. Bansal et al, 1991; Pérez-Sala and Molinedo, 1994; Han and Wyche, 1996). Also, neither the action of clofibrate as enzyme inducer (see Introduction) nor the suggestion that PP toxicity may result from PPAR interferring with retinoid action (Green and Wahli, 1994) can be disregarded. The status of the PPAR expression in the different cells herewith tested is currently under investigation and we ignore whether it is related to the present differential effects. However, the rapidity of the lethal effect of clofibrate on $\mathrm{AH}-130$ or HepG2 cells might be difficult to reconcile with the possibility of an involvement of the PPAR. On the other hand, clofibrate and other PPs are known to exert antiproliferative and differentiation-promoting effects on cells such as 3T3-L1 preadipocytes (Chawla and Lazar, 1994) and, in normal rat liver, clofibrate can stimulate the production of TGF- $\beta$ (Rumsby et al, 1994), which is a known inhibitor of growth and inducer of apoptosis on rodent hepatocytes or rodent and human hepatoma cells (Lin and Chou, 1992; Bursch et al, 1993; Fukuda et al, 1993).

Nafenopin at $0.05 \mathrm{mM}$ concentration has been recently shown to suppress apoptosis, whether spontaneous or elicited by agents such as TGF- $\beta$, and to promote cell survival of primary hepatocyte cultures and cells of the $\mathrm{FaO}$ rat hepatoma line (Bayly et al, 1994; Gill et al, 1995). On the $\mathrm{AH}-130$ cells, not only we did not observe any protection of $0.05 \mathrm{mM}$ nafenopin against spontaneous or clofibrate-induced apoptosis, but, rather, $1 \mathrm{mM}$ nafenopin 
was as apoptogenic as clofibrate. Whether the reason for such divergent effects pertains to the cell type is not known as yet and deserves further investigations.

\section{Possible significance of the lethal action of clofibrate}

Two apparently contradictory effects have been reported for PPs as tumor promoters. Short-term treatment consistently causes a decrease in the number and size of glutathione Stransferase $\mathrm{P} 1-1$ or $\gamma$-glutamyltranspeptidase-positive preneoplastic lesions, whereas longer treatment results in more and larger tumors in livers with the same preneoplastic lesions (Chen et al, 1994, and references therein). The phenotypic shifts observed in preneoplastic hepatic lesions in response to short-term treatment with PP may reflect inhibition of certain subsets of cell populations and promotion of others (Chen et al, 1994). Whether changes in rates of cell proliferation or of cell deletion or of both processes are involved is not entirely clear. In the course of chemical carcinogenesis, preneoplastic liver lesions are known to undergo extensive remodelling and cell turnover (Columbano et al, 1984; Rotstein et al, 1986; Bursch et al, 1992; Canuto et al, 1993; Chen et al, 1994; Piga et al, 1995), implying that they contain a significant proportion of cells whose survival is compromised. Under such circumstances, additional stimulation with a PP could further upset the finely-tuned balance of extra- and intracellular signals, to such an extent as to precipitate cell death (Wyllie, 1992; Passilly et al, 1996).

Irrespective of the precise underlying mechanism(s), the observation that clofibrate exerts strong lethal action on cells of both rodent and human origin such as the $\mathrm{AH}-130$ and the HepG2 suggests that the cytotoxicity of clofibrate and related agents on normal and, particularly, tumoural cells may deserve careful reevaluation.

\section{Materials and methods}

\section{Cells and treatments}

Male Long-Evans rats, weighing $120-150 \mathrm{~g}$ and maintained on a semi-synthetic diet (Piccioni, Brescia, Italy) and water ad libitum were used for serial weekly transplantation of the Yoshida $\mathrm{AH}-130$ ascites hepatoma $\left(20-30 \times 10^{6}\right.$ tumour cells inoculated i.p. in $\left.1 \mathrm{ml}\right)$. Under sterile conditions, 6 day-old ascites tumours were collected with a syringe and cells were separated from the ascitic fluid by low-speed centrifugation, washed in RPMI 1640 medium, resuspended $\left(4 \times 10^{6} /\right.$ $\mathrm{ml}$ ) in the same medium supplemented with $10 \%$ newborn calf serum, $1 \%(\mathrm{w} / \mathrm{v})$ bovine serum albumin (fraction $\mathrm{V}$, fatty acid free), and transferred to Petri dishes.

Rat hepatocytes were isolated according to standard procedures (Seglen, 1973) and cultured as indicated by Bayly et al. (1994). HepG2 cells, derived from a human hepatoblastoma, were grown in DMEM supplemented with $10 \%$ foetal calf serum in standard conditions.

Clofibrate, dissolved in dimethylsulphoxide, or nafenopin, dissolved in $\mathrm{N}-\mathrm{N}$-dimethylformamide, were added (1:100 in volume) to culture media to the final concentrations specified. Controls were treated with solvents alone. HepG2 cells were incubated for $2-4-8 \mathrm{~h}$ and the other cells for 4 or $24 \mathrm{~h}$ at $37^{\circ} \mathrm{C}$ in a humidified atmosphere of $5 \% \mathrm{CO}_{2}$ in air, then harvested and analyzed.

\section{DNA distribution}

DNA staining was performed as described elsewhere (Barbiero et al, 1995), with some modifications (Bianciotto et al, 1995). Briefly, cells were washed in PBS, fixed in ice-cold $70 \%$ ethanol for at least $30 \mathrm{~min}$, incubated at room temperature in PBS containing DNase-free RNase (Type II-A) and PI at final concentrations of 0.4 and $0.18 \mathrm{mg} / \mathrm{ml}$, respectively, then analyzed with a FACScan flow cytometer (Becton \& Dickinson, Mountain View, CA, USA) equipped with a $488 \mathrm{~nm}$ argon laser and two filters, respectively transmitting at $585 \mathrm{~nm}$ (FL2) and above $620 \mathrm{~nm}$ (FL3). FSC and SSC were measured simultaneously. Data were recorded on a Hewlett Packard computer (HP 9000, model 300), using CellFit software (Becton \& Dickinson).

\section{Cell integrity}

A panel of independent parameters was used.

Plasma membrane integrity was checked both microscopically and flow cytometrically. TB exclusion was evaluated on cells suspended in the presence of the dye $(0.8 \mathrm{mg} / \mathrm{ml}) ; 400$ cells were counted for each sample and results expressed as percentages of TB-positive cells. For the PI-exclusion test, cells unfixed and suspended in PBS $\left(10^{6}\right.$ cells/ $\mathrm{ml})$ were incubated with $\mathrm{PI}(10 \mu \mathrm{g} / \mathrm{ml})$ and analyzed by flow cytometry as detailed elsewhere (Barbiero et al, 1995).

Mitochondrial transmembrane potential was evaluated by a R123retention test. Unfixed AH-130 cells suspended in PBS (106 cells/ml) were incubated for $30 \mathrm{~min} 37^{\circ} \mathrm{C}$ with R123 $(10 \mu \mathrm{g} / \mathrm{ml})$ and analyzed by flow cytometry as described elsewhere (Barbiero et al, 1995). In some experiments cells were both preincubated with $\mathrm{R} 123$ and subsequently stained with $\mathrm{PI}$, as specified above, to compare $\mathrm{PI}$ exclusion and $\mathrm{R} 123$ retention.

LDH activity was assayed (Kornberg, 1955) on total cell suspensions, after sonication, and on clear supernatants after centrifugation at $600 \times g$ for $10 \mathrm{~min}$. The activity determined in the supernatant was expressed as percentage of total activity in the cell suspension.

\section{DNA fragmentation}

The occurrence of internucleosomal DNA fragmentation was evaluated by the AGE method as described by Kaufmann (1989). Cells were washed twice with ice-cold phosphate-buffered saline, suspended at $2 \times 10^{6}$ cells $/ \mathrm{ml}$ in a lysis buffer ( $2 \mathrm{mM} \mathrm{EDTA}, 10 \mathrm{mM}$ $\mathrm{NaCl}, 1 \%$ sodium dodecyl sulphate, $500 \mathrm{mM}$ Tris- $\mathrm{HCl}, \mathrm{pH} 9.0$ ), incubated with RNAse $(20 \mu \mathrm{g} / \mathrm{ml})$ for $1 \mathrm{~h}$ at $37^{\circ} \mathrm{C}$ and then with proteinase $\mathrm{K}(100 \mu \mathrm{g} / \mathrm{ml})$ for $1 \mathrm{~h}$ at $37^{\circ} \mathrm{C}$, and finally extracted with phenol/chloroform. Aliquots of $10 \mu \mathrm{g}$ DNA were electrophoresed on a $1.0 \%$ agarose gel and viewed under UV illumination after staining with ethidium bromide $(0.5 \mu \mathrm{g} / \mathrm{ml})$.

\section{Light microscopy}

Cells were fixed in methanol, stained with the DNA-specific fluorochrome DAPI and examined in an epiilluminated fluorescence microscope (Dialux, Leitz, Germany). The apoptotic index (percentage of apoptotic cells) was determined on at least 1000 cells per sample.

\section{Statistical analysis}

Data are expressed as means \pm SD. Significance of differences was assessed by ANOVA, followed by the Newman-Keuls test. 


\section{Chemicals}

Nafenopin (2-methyl-2[1,2,3,4-(tetrahydro-1-naphtyl)-phenoxyl]prionic acid) was a kind gift from Ciba-Geigy (Basel, Switzerland); DAPI was purchased from Boehringer Mannheim (Germany); clofibrate (2-(pchlorophenoxy)-2-methyl-propionic acid ethyl ester), DNase-free RNase (Type II-A), PI, R123, and other reagents from Sigma (St. Louis, MO, USA).

\section{Acknowledgements}

The authors are grateful to Dr. Sebastiano Colombatto for providing primary hepatocyte cultures. Work supported by grants from the Ministero per I'Università e la Ricerca Scientifica e Tecnologica, Rome, the Consiglio Nazionale delle Ricerche (CNR, Special Project ACRO), Rome, and the Associazione Italiana per la Ricerca sul Cancro, Milan. G. Barbiero was recipient of a fellowship from the Comitato Regionale Piemontese Gigi Ghirotti, Turin, and then from CNR (Special Project Invecchiamento), Rome.

\section{References}

Amenta JS, Sargus MJ, Baccino FM, Sacchi C and Bonelli G (1993) Cell death induced in L-cells by treatment with thymidine: staging of the process and relationship to apoptosis. In Vitro Cell Dev. Biol. 29A: 855-861

Bansal N, Houle A and Melnykovych G (1991) Apoptosis: mode of cell death induced in T cell leukemia lines by dexamethasone and other agents. FASEB J. 5:211216

Barbiero G, Duranti F, Bonelli G, Amenta JS and Baccino FM (1995) Intracellularionic variations in the apoptotic death of $L$ cells by inhibitors of cell cycle progression. Exp. Cell Res. 217: 410-418

Bianciotto V, Barbiero G and Bonfante P (1995) Analysis of cell cycle in an arbuscular mycorrhizal fungus by flow cytometry and bromodeoxyuridine labelling. Protoplasma 188: 161-169

Bayly AC, Roberts RA and Dive C (1994) Suppression of liver cell apoptosis in vitro by the non-genotoxic hepatocarcinogen and peroxisome proliferator nafenopin. J. Cell Biol. 125: 197-203

Bursch W, Fesus L and Schulte-Hermann R (1992) Apoptosis ('programmed cell death') and its relevance in liver injury and carcinogenesis, in Tissue-Specific Toxicity: Biochemical Mechanisms, Dekant W and Neumann HG eds., (London: Academic Press) pp. 95-115

Bursch W, Oberhammer F, Jirtle RL, Askari M, Sedivy R, Grasl-Kraupp B, Purchio AF and Schulte-Hermann R (1993) Transforming growth factor- $\beta_{1}$ as a signal for induction of cell death by apoptosis. Br. J. Cancer. 67: 531-536

Canuto RA, Tessitore L, Muzio G, Autelli R and Baccino FM (1993) Tissue protein turnover during chemical hepatocarcinogenesis. Carcinogenesis 14: $2581-$ 2587

Castillo M, Burgos C, Rodriguez-Vico F, Zafra MF and Garcia-Peregrin E (1990) Effects of clofibrate on the main regulatory enzymes of cholesterogenesis. Life Sci. 46: 397-403

Chawla A and Lazar MA (1994) Peroxisome proliferator and retinoid signaling pathways co-regulate preadipocyte phenotype and survival. Proc. Natl. Acad. Sci. USA. 91: 1786-1790

Chen ZY, Liu YF, He CY, White CC, and Eaton DL (1994) Inhibition of cell proliferation by ciprofibrate in glutathione S-transferase $\mathrm{P} 1$-1-positive rat hepatic hyperplastic nodules. Cancer Res. 54: 2622-2629

Columbano A, Endoh T, Denda A, Noguchi O, Nakae D, Hasegawa K, LeddaColumbano GM, Zedda Al and Konishi Y (1996) Effects of cell proliferation and cell death (apoptosis and necrosis) on the early stages of rat hepatocarcinogenesis. Carcinogenesis 17: 395-400

Columbano A, Ledda-Columbano GM, Rao PM, Rajalakshmi S and Sarma DSR (1984) Occurrence of cell death (apoptosis) in preneoplastic and neoplastic liver cells. A sequential study. Am. J. Pathol. 116: 441-446

Darzynkiewicz Z, Bruno S, Del Bino G, Gorczyca W, Hotz MA, Lassota P and Traganos $F$ (1992) Features of apoptotic cells measured by flow cytometry. Cytometry 13: 795-808
Desjardins LM and MacManus JP (1995) An adherent cell model to study different stages of apoptosis. Exp. Cell Res. 216: 380-387

Dive C, Gregory CD, Phipps DJ, Evans DL, Milner AE and Wyllie AH (1992) Analysis and discrimination of necrosis and apoptosis (programmed cell death) by multiparameter flow cytometry. Biochim. Biophys. Acta 1133: 275-285

Fukuda K, Kojiro M and Chiu JF (1993) Induction of apoptosis by transforming growth factor- $\beta 1$ in the rat hepatoma cell line McA-RH7777: a possible association with tissue transglutaminase expression. Hepatology. 18: 945-953

Gill JH, Molly CA, Shoesmith KJ, Bayly AC and Roberts RA (1995) The rodent nongenotoxic hepatocarcinogen Nafenopin and EGF alter the mitosis/apoptosis balance promoting hepatoma cell clonal growth. Cell Death Differ. 2: 211-217

Green S and Wahli W (1994) Peroxisome proliferator-activated receptors: finding the orphan a home. Mol. Cell. Endocrinol. 100: 149-153

Hahn SE and Goldberg D (1992) Modulation of lipoprotein production in HEP G2 cells by fenofibrate and clofibrate. Biochem. Pharmacol. 43: 625-633

Han Z and Wyche JH (1996) Lovastatin induces apoptosis in a metastatic ovarian tumour cell line. Cell Death Differ. 3: 223-228

Haughom B and Spydevold O (1992) The mechanism underlying the hypolipidemic effect of perfluorooctanoic acid (PFOA), perfluorooctane sulphonic acid (PFOSA) and clofibric acid. Biochim. Biophys. Acta. 1128: 65-72

Hwang JJ, Stephen MT and Jirtle RL (1993) Induction of sister chromatid exchange and micronuclei in primary culture of rat and human hepatocytes by the peroxisome proliferator, Wy-14643. Mutat. Res. 286: 123-133

Hickman JA (1992) Apoptosis induced by anticancer drugs. Cancer Metast. Rev. 11: $121-139$

Kaufmann SH (1989) Induction of endonucleolytic DNA cleavage in human acute myelogenous leukemia cells by etoposide, camptothecin and other cytotoxic anticancer drugs: a cautionary note. Cancer Res. 49: 5870-5878

Khan SH and Sorof S (1994) Liver fatty acid-binding protein: specific mediator of the mitogenesis induced by two classes of carcinogenic peroxisome proliferators. Proc. Natl. Acad. Sci. USA. 91: 848-852

Kornberg A (1955) Lactic dehydrogenase of muscle. Methods Enzymol. 1: 441-443

Kroemer G, Petit P, Zamzami N, Vayassière JL and Mignotte B (1995) The biochemistry of programmed cell death. FASEB J. 9: 1277-1287

Lin JKand Chou CK (1992) In vitro apoptosis in the human hepatoma cell line induced by transforming growth factor $\beta_{1}$. Cancer Res. 52: 385-388

Nicoletti I, Migliorati G, Pagliacci MC, Grignani F and Riccardi C (1991) A rapid and simple method for measuring thymocyte apoptosis by propidium iodide staining and flow cytometry. J. Immunol. Meth. 139: 271-279

Ohmura T, Ledda-Columbano GM, Piga R, Columbano A, Glemba J, Katyal SL, Locker J and Shinozuka H (1996) Hepatocyte proliferation induced by a single dose of a peroxisome proliferator. Am. J. Pathol. 148: 815-824

Parekh H and Chitnis M (1991) Differential alteration of cellular lipids in drug sensitive and resistant P388 leukemia cells by clofibrate: effects on mitoxantrone cytotoxicity. Tumori 77: 105-111

Passilly P, Jannin B, Hassell SJ and Latruffe N (1996) Human HepG2 and rat Fao hepatic-derived cell lines show different responses to ciprofibrate, a peroxisome proliferator: analysis by flow cytometry. Exp. Cell Res. 223: 436-442

Peitsch MC, Mannherz HG and Tschopp J (1994) The apoptosis endonucleases: cleaning up after cell death? Trends Cell Biol. 4: 37-41

Pérez-Sala D and Molinedo F (1994) Inhibition of isoprenoid biosynthesis induces apoptosis in human promyeolcytic HL-60 cells. Biochem. Biophys. Res. Commun. 199: 1209-1215

Perrot N, Chesne C, De Waziers I, Beaune PH and Guillouzo A (1991) Effects of ethanol and clofibrate on expression of cytochrome P-450 enzymes and epoxide hydrolase in cultures and cocultures of rat hepatocytes. Eur. J. Biochem. 200: $255-261$.

Piga R, Zedda Al, Ledda-Columbano GM and Columbano A (1995) Role of apoptosis in the early stages of chemical carcinogenesis. Fund. Clin. Immunol. 3: 74-75.

Reddy JKand LalwaiND (1983) Carcinogenesis by hepatic peroxisome proliferators: evaluation of the risk of hypolipidemic drugs and industrial plasticizers to humans. Crit. Rev. Toxicol. 12: 1-58.

Rodriguez JC, Gil-Gomez G, Hegardt FG, and Haro D (1994) Peroxisome proliferator-activated receptor mediates induction of the mitochondrial 3 hydroxy-3-methylglutaryl-CoA synthase gene by fatty acids. J. Biol. Chem. 269: $18767-18772$

Rotstein J, Sarma DSR and Farber E (1986) Sequential alterations in growth control and cell dynamics of rat hepatocytes in early precancerous steps in hepatocarcinogenesis. Cancer Res. 46: 2377-2385 
Rumsby PC, Davies MJ, Price RJ and Lake BG (1994) Effect of some peroxisome proliferators on transforming growth factor- $\beta_{1}$ gene expression and insulin-like growth factor II/mannose-6-phosphate receptor gene expression in rat liver. Carcinogenesis 15: 419-421

Schulte-Hermann R, Parzefall W and Bursch W (1987) Role of stimulation of live growth by chemicals in hepatocarcinogenesis, in Banbury Report 25: Nongenotoxic Mechanisms in Carcinogenesis, Butterworth BE and Slaga TJ eds. (New York: Cold Spring Harbor) pp. 91-106

Seglen PO (1973) Preparation of rat liver cells. III. Enzymatic requirements for tissue digestion. Exp. Cell Res. 82: 391-398

Sherwood SW and Schimke RT (1994) Induction of apoptosis by cell-cycle specific drugs, in Apoptosis, Mihich E and Schimke RT eds. (New York: Plenum Press) pp. 223-236
Swat W, Ignatowicz $L$ and Kisielow $P$ (1991) Detection of apoptosis of immature $\mathrm{CD}^{+} 8^{+}$thymocytes by flow cytometry. J. Immunol. Meth. 137: 79-87

Telford WG, King LE and FrakerPJ (1991) Evaluation of glucocorticoid-induced DNA fragmentation in mouse thymocytes by flow cytometry. Cell Prolif. 24: 447-459

Tessitore L, Costelli P, Sacchi C, Piacentini M and Baccino FM (1993) The role of apoptosis in growing and stationary rat ascites hepatoma, Yoshida $\mathrm{AH}-130$. J. Pathol. 171: 301-309

Thorp JM and Waring WS (1962) Modification of metabolism and distribution of lipids by ethyl chlorophenoxyisobutyrate. Nature 194: $948-949$

Wyllie AH, Kerr JFR and Currie AR (1980) Cell death: the significance of apoptosis. Int. Rev. Cytol. 68: 251-306

Wyllie AH (1992) Apoptosis and the regulation of cell numbers in normal and neoplastic tissues: an overview. Cancer Metast. Rev. 11: 95-103 